\title{
DAR DAN PERPUTARAN PERSEDIAAN SERTA PENGARUHNYA TERHADAP PROFITABILITAS \\ PERUSAHAAN TEKSTIL DAN GARMEN YANG TERDAFTAR DI INDEKS SAHAM SYARIAH \\ INDONESIA 1 )
}

Rizky Aprilian Kusuma Dewi

Program Studi S1 Ekonomi Islam-Fakultas Ekonomi dan Bisnis-Universitas Airlangga

Email : kikyaprilian@gmail.com

Ari Prasetyo

Departemen Ekonomi Syariah-Fakultas Ekonomi dan Bisnis-Universitas Airlangga

Email : ari_feunair@yahoo.co.id

\begin{abstract}
:
The purpose of this reserach is to find out the significant effect of the two variable debt to assets ratio and inventory turn over of the profitability with the measuring instrument Return On Assets. The method used in this study is quantitative method with secondary data sources. The samples in this study are the tekstil and garment companies that are still registered in Indonesia Sharia Stock Index, publishing their three month report completely from 2012 to September 2015. There are seven companies that will become the samples. The technique used in this study is panel data regression analysis technique. The result of this research indicate that the inventory turnover partially provide a significant influence on ROA, and debt to assets ratio partially provide an unsignificant influence on ROA. Simultaneously, inventory turn over dan debt to assets ratio providea significant influence ROA.
\end{abstract}

Keywords: DAR, ITO, profitability, Indonesia Sharia Stock Index

\section{PENDAHULUAN}

Kebutuhan manusia akan sandang, pangan, dan papan tentu membutuhkan penyedia atau supplier guna memenuhi kebutuhan tersebut. Banyak industri yang bergerak di bidang sandang, pangan dan papan tersebut dan hasil atau outputnya dimanfaatkan oleh masyarakat. Salah satu industri yang sangat dekat, outputnya banyak dipakai dan sangat dibutuhkan oleh masyarakat adalah industri tekstil dan garment. Kebutuhan masyarakat yang besar terhadap kebutuhan sandang atau produk dari industri tekstil dan garment tentu dapat menjadi peluang yang besar bagi industri ini untuk berkembang. Tidaklah heran apabila industri ini sangat berkembang baik di dalam maupun di luar negeri.

Pada tahun 2014 omset domestik dari industri tekstil dan garment mencapai 70 triliun. Disisi lain nilai ekspor salah satu produk tekstil dan garment menuai prestasi yang cukup membanggakan, selama rentang waktu 2011-2014 nilai ekspor pakaian jadi teringgi ada pada tahun 2013 yaitu sebesaar 470,369,8 ton. Pada tahun 2012 nilai ekspor tekstil mencapai angka 21,4 miliar. Sedangkan pada tahun 2013 berada diangka 12,6 miliar. Pada tahun 2019 dapat diperkirakan bahwa nilai ekspor

1) Jurnal ini merupakan bagian dari skripsi dari Rizky Aprilian Kusumadewi, NIM : 041114106 , yang diuji pada 12 Februari 2016 
Dewi, et al/Jurnal Ekonomi Syariah Teori dan Terapan Vol. 3 No. 7 Juli 2016: 520-532; DAR DAN PERPUTARAN PERSEDIAAN SERTA PENGARUHNYA TERHADAP PROFITABILITAS PERUSAHAAN TEKSTIL DAN GARMEN YANG TERDAFTAR DI INDEKS SAHAM SYARIAH INDONESIA

tekstil nasional akan tumbuh sebesar $300 \%$.

Prestasi perusahaan tekstil dan garment memang sangat membanggakan, namun krisis pada tahun 2009 memberikan pengaruh yang cukup dalam pada perusahaan tekstil dan garment. Penilaian bank Indonesia terhadap perusahaan tekstil dan garment berdasarkan peraturan Bank Indonesia No 8/2/2006 memberikan hasil bahwa industri tekstil dan garment bukan merupakan industri yang memiliki hasil penillian yang bagus. Disamping itu, ketua Asosiasi Pertekstilan Indonesia (API) Ade Sudrajat, industri tekstil dan garmen mengalam tantangan berat pada tahun 2015 dikarenakan melemahnya pasar Amerika Serikat dan resesi Jepang. Selain itu juga disebabkan oleh fluktuatifnya harga BBM. Ade Sudrajat juga menyatakan bahwa tantangan berat lainnya berasal dari adanya pajak kapas dari barang tidak kena pajak menjadi barang kena pajak yakni sebesar $10 \%$.

Keadaan diatas tentu mempengaruhi modal perusahaan. Sebuah perusahaan harus mampu mengelola modalnya dengan baik. Jika modal perusahaan dirasa tidak mecukupi untuk kegiatan perusahaan maka perusahaan dapat memasukkan dana kesternal.
Namun dana eksternal dan internal harus diseimbangkan. Rasio sovabilitas dapat membantu perusahaan guna mengetahui kemampuan perusahaan membayar seluruh kewajibannya, baik jangka pendek maupun jangka panjang apabila perusahaan dibubarkan (dilikuidasi) (Kasmir, 2013:151). Jika nilai hutang perusahaan terlalu tinggi maka beban yang ditanggung peusahaan juga akan tinggi hal tersebut tentu mempengaruhi perusahaan dalam hal profitabilitas. Begitu pula sebaliknya. Sebuah perusahaan boleh saja mengambil dana eksternal guna membantu pendanaan aktivitas perusahaan, namun hal tersebut harus benarbenar diperhatikan agar tidak membebani perusahaaan sendiri.

Faktor lain yang mempengaruhi profitabilitas perusahaan adalah dari sisi aktivitas perusahaan itu sendiri. Sisi pejualan, perputaran persediaan dan lain sebagainya. Rasio aktivitas adalah rasio yang digunakan untuk mengetahui aktivitas perusahaan dalam menjalankan operasinya, baik dalam penjualan maupun kegiatan lainnya (Mulyawan, 2015:116). Salah satu perhitungan rasio aktivitas adalah inventory turn over. Dari perhitungan inventory turn over tersebut dapat diketahui 
Dewi, et al/Jurnal Ekonomi Syariah Teori dan Terapan Vol. 3 No. 7 Juli 2016: 520-532; DAR DAN PERPUTARAN PERSEDIAAN SERTA PENGARUHNYA TERHADAP PROFITABILITAS PERUSAHAAN TEKSTIL DAN GARMEN YANG TERDAFTAR DI INDEKS SAHAM SYARIAH INDONESIA

berapa kali persediaan berputar pada satu tahun. Jika perputaran persediaan ini tinggi, maka biaya untuk perawatan persediaan tersebut menjadi rendah, jika biaya tersebut rendah maka perusahaan akan mendapat kesempatan untuk memperbesar profitabilitasnya.

Penelitian ini meneliti tentang profitabilitas perusahaan tekstil dan garment, hal ini dikarenakan pada waktu krisis dunia yang terjadi pada periode 2008 sampai 2009 salah satu perusahaan yang terkena dampaknya adalah kelangsungan industri manufaktur terutama perusahaan tekstil dan garment. Hal ini terjadi karena sektor real estate dan properti adalah perusahaan yang sangat peka terhadap pasang surut perekonomian di Indonesia.

Dalam rasio solvabilitas sendiri ada pengukuran DAR. Seperti yang dijelaskan oleh Hery (2015:195) "Membandingkan jumlah kewajiban dengan jumlah aset yang dimiliki perusahaan menunjukkan sejauh mana dana yang dipinjam telah digunakan untuk membeli aset."

ITO menunjukkan berapa kali persediaan berputar pada satu tahun. Sehingga semakin tinggi ITO maka hal ini menunjukkan efektifnya perusahaan dalam mengelola persediaannya. Jika nilai ITO ini tinggi maka beban perawatan untuk ersediaan akan rendah dana oerusahaan akan mendapatkan kesempatan untuk menaikkan tingkat profitabilitasnya.

\section{LANDASAN TEORI}

"Rasio kevangan adalah angka yang diperoleh dari hasil perbandingan antara satu pos laporan keuangan dengan pos lainnya yang mempunyai hubungan yang relevan dan signifikan" (Hery, 2015:161-162).

Pengertian rasio keuangan menurut Van Home dalam Kasmir (2013:104) merupakan indeks yang menghubungkan dua angka akuntansi dan diperoleh dengan membagi satu angka dengan lainnya. Rasio keuangan merupakan suatu perhitungan rasio dengan menggunakan laporan keuangan yang berfungsi sebagai alat ukur dalam menilai kondisi keuangan dan kinerja perusahaan. Hasil rasio keuangan ini akan menunjukkan kondisi kesehatan perusahaan. Jadi dapat disimpulkan bahwa rasio keuangan merupakan kegiatan membandingkan angka-angka yang ada dalam laporan keuangan dengan cara membagi satu angka dengan angka lainnya yang berguna untuk melihat kondisi keuangan sebuah perusahaan serta untuk membantu management guna mengambil keputusan untuk periode mendatang.

Analisis rasio merupakan bagian dari analisis keuangan. Analisis rasio 
Dewi, et al/Jurnal Ekonomi Syariah Teori dan Terapan Vol. 3 No. 7 Juli 2016: 520-532; DAR DAN PERPUTARAN PERSEDIAAN SERTA PENGARUHNYA TERHADAP PROFITABILITAS PERUSAHAAN TEKSTIL DAN GARMEN YANG TERDAFTAR DI INDEKS SAHAM SYARIAH INDONESIA

\begin{abstract}
adalah analisis yang dilakukan dengan menghubungkan berbagai perkiraan yang ada pada laporan keuangan dalam bentuk rasio keuangan. "Rasio kevangan dirancang untuk membantu mengevaluasi laporan keuangan" (Houston dan Brigham, 2001: 79).

"Rasio profitabilitas adalah merupakan rasio untuk menilai kemampuan perusahaan dalam mengahasilkan keuntungan" (Kasmir, 2013:196). Sedangkan menurut Mulyawan (2015:115) "rasio profitabilitas adalah kemampuan perusahaan medapatkan laba melalui semua sumber yang ada, penjualan, kas, aset, dan modal".
\end{abstract}

Rasio profitabilitas terdiri dari beberapa jenis. Masing-masing dari jenis tersebut memiliki fungsinya masing-masing. Jenis-jenis rasio profitabilitas menurut Hery (2015:228) tersebut adalah :

a. Return On Assets (ROA) merupakan perbandingan antara laba bersih dengan total aset. Rasio ini mencerminkan seberapa besar jumlah laba yang akan dihasilkan dari setiap rupiah dana yang ditanam dalam total aset.

b. Return On Equity (ROE) rasio ini mengukur seberapa besar jumlah laba bersih yang akan dihasilkan oleh setiap rupiah yang tertanam pada ekuitas. Rasio ini dapat dihitung dengan membagi antara laba bersih dan total ekuitas

c. Margin Laba Kotor merupakan rasio yang digunakan untuk mengukur besarnya persentase laba kotor atas penjualan bersih.

d. Margin Laba Operasional rasio ini dihitung dengan membagi laba operasional dengan laba bersih. Gunanya adalah untu mengukur besar persentase laba operasional atas laba bersih.

e. Margin Laba Bersih rasio yang digunakan untuk mengukur besarnya persentase laba bersih terhadap penjualan bersih. Laba bersih dihitung sebagai hasil pengurangan antara laba sebelum pajak dengan beban pajak penghasilan.

Mendapatkan profit atau keuntungan memang merupakan tujuan sebuah perusahaan didirikan. Namun keuntungan tersebut tidak boleh diperoleh dengan cara yang buruk atau menyengsarakan orang lain. Seperti firman Allah SWT dalam surat An-Nisa ayat 29 : 
Dewi, et al/Jurnal Ekonomi Syariah Teori dan Terapan Vol. 3 No. 7 Juli 2016: 520-532; DAR DAN PERPUTARAN PERSEDIAAN SERTA PENGARUHNYA TERHADAP PROFITABILITAS PERUSAHAAN TEKSTIL DAN GARMEN YANG TERDAFTAR DI INDEKS SAHAM SYARIAH INDONESIA

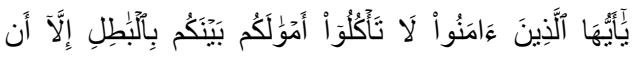

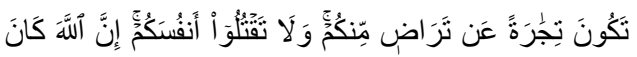

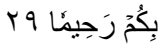

Yā ayyuhālladzīna āmanū lā ta'kulū amwālakum bainakum bil bāthil illā an takūna tijāratan an tarādhin minkum walā taqtulū anfusakum innAllaha kāna bikum rahiim

Artinya : Hai orang-orang yang beriman, janganlah kamu saling memakan harta sesamamu dengan jalan yang batil, kecuali dengan jalan perniagaan yang berlaku dengan suka sama-suka di antara kamu. Dan janganlah kamu membunuh dirimu; sesungguhnya Allah adalah Maha Penyayang kepadamu (QS. An-Nisa 29) (Departemen Agama Rl, 2007)

Rasio ini menunjukkan seberapa

besar kontribusi aset dalam menciptakan laba bersih. Rasio ini digunakan untuk mengetahui seberapa besar laba bersih yang dihasilkan dari dana yang ditanam dalam aset. "Semakin tinggi rasio ini berarti semakin tinggi pula jumlah laba bersih yang dihasilkan setiap rupiah dana yang tertanam dalam aset" (Hery, 2015:228).

Perusahaan menyukai nilai return on assets (ROA) yang tinggi, karena hal iitu berati bahwa laba bersih yang didapat oleh perusahaan tinggi. Dapat diartikan juga bahwa saat nilai ROA ini tinggi, bahwa perusahaan tidak memiliki jumlah aset yang tidak produktif dalam jumlah yang besar, telah ada pemanfaatan secara maksimal dari aset untuk menciptakan penjualan.
Beban yang ditanggung perusahaan berada pada jumlah yang kecil juga dapat menjadi faktor yang menyebabkan ROA ini tinggi. Untuk menghitung nilai ROA dapat menggunakan rumus (Briaham 2013:148):

$\begin{aligned} & \text { Pengembalian atas total asset } \\ & (\text { ROA }): \frac{\text { Laba Bersih }}{\text { Asset }}\end{aligned}$
Rasio solvabilitas atau rasio leverage merupakan rasio yang digunakan untuk mengukur sejauh mana aset perusahaan dibiayai dengan hutang. Dengan kata lain rasio ini merupakan rasio yang digunakan untuk mengukur seberapa besar beban hutang yang harus ditanggung perusahaan dalam rangka pemenuhan aset(Hery, 2015:190). Rasio ini sangat penting karena dapat membantu perusahaan mengetahui bagaimana keadaan hutang perusahaan tersebut.

Kasmir (2013:152) menyatakan bahwa:

"Dalam praktiknya apabila hasil dari perhitungan ternyata perusahaan memiliki rasio solvabilitas tinggi hal ini akan berdampak timbulnya resiko kerugian yang besar, tetapi kesempatan untuk mendapatkan laba juga besar. Hal sebaliknya terjadi saat sebuah perusahaan memiliki rasio solvabilitas rendah, maka hal ini dapat berpengaruh 
Dewi, et al/Jurnal Ekonomi Syariah Teori dan Terapan Vol. 3 No. 7 Juli 2016: 520-532; DAR DAN PERPUTARAN PERSEDIAAN SERTA PENGARUHNYA TERHADAP PROFITABILITAS PERUSAHAAN TEKSTIL DAN GARMEN YANG TERDAFTAR DI INDEKS SAHAM SYARIAH INDONESIA

pada rendahnya resiko kerugian yang akan dialami oleh perusahaan terutama saat perekonomian menurun, dampak lain yang diakibatkan rasio solvabilitas rendah pada perusahaan adalah rendahnya tingkat pengembalian saat perekonoman tinggi"

Dana atau modal merupakan hal yang penting bagi sebuah perusahaan. Ketersediaan serta sumber dana harus benar-benar dipikirkan dengan baik dan matang, sehingga nantinya tidak menjadi beban bagi perusahaan. Perusahaan sangat bergantung pada ketersediaan modal dana, dana yang ada di perusahaan akan digunakan untuk operasional perusahaan. Namun perusahaan harus menyeimbangkan antara dana internal dan dana eksternal perusahaan.

Kasmir (2013:156) menerangkan beberapa jenis rasio solvabilitas, diantaranya yaitu :

a. Debt To Assets Ratio (DAR) Rasio ini merupakan rasio utang yang digunakan untuk mengukur perbandingan antara total hutang dengan total aktiva. Tujuannya adalah untuk mengetahui seberapa besar aktiva perusahaan dibiayai hutang. b. Debt To Equity Ratio (DER). Rasio ini digunakan untuk menilai hutang dengan ekuitas, dengan cara membandingkan antara seluruh hutang dengan seluruh ekuitas.

c. Long Term Debt To Equity Ratio. Rasio ini hanya mengukur utang jangka panjang dengan modal sendiri. Tujuannya untuk mngukur berapa bagian dari setiap modal sendiri yang dijadikan jaminan hutang jangka panjang.

Rasio ini menerangkan seberapa besar aktiva perusahaan dibiayai oleh hutang, atau seberapa besar hutang berpengaruh terhadap pengelolaan aset. "Membandingkan jumlah kewajiban dengan jumlah aset yang dimiliki perusahaan menunjukkan sejauh mana dana yang dipinjam telah digunakan untuk membeli aset" (Hery, 2015:195). Tingginya hutang pada sebuah perusahaan dapat menyebabkan perusahaan tersebut sulit mendapatkan pinjaman lagi. Hal ini berkaitan dengan kemampuan perusahaan tersebut untuk membayar hutangnya dengan aset yang dimiliki. Untuk menghitung rasio ini dapat menggunakan rumus (Brigham dan Houston, 2013:143) :

Debt To Asset Ratio (DAR) : Total Debt 
Dewi, et al/Jurnal Ekonomi Syariah Teori dan Terapan Vol. 3 No. 7 Juli 2016: 520-532; DAR DAN PERPUTARAN PERSEDIAAN SERTA PENGARUHNYA TERHADAP PROFITABILITAS PERUSAHAAN TEKSTIL DAN GARMEN YANG TERDAFTAR DI INDEKS SAHAM SYARIAH INDONESIA

\begin{tabular}{|} 
Debt To Asset Ratio (DAR) : \\
$\frac{\text { Total Debt }}{\text { Total Asset }}$ \\
\hline
\end{tabular}

Rasio aktivitas merupakan rasio yang digunakan untuk mengukur efektivitas perusahaan dalam menggunakan aset yang dimilikinya, termasuk untuk mengukur tingkat efisiensi perusahaan dalam memanfaatkan sumber daya yang ada (Hery, 2015:209). Berdasarkan hasil pengukuran rasio tersebut dapat disimpulkan apakah perusahaan telah secara efisien dan efektif dalam memanfaatkan sumber daya yang dimilikinya. Rasio ini akan menjawab pertanyaan apakah jumlah setiap jenis aset terlihat wajar, terlalu tinggi, atau terlalu rendah jika dilihat dari penjualan saat ini dan proyeksinya. Jika perusahaan memiliki terlalu banyak aset yang menggangur, maka biaya modalnya terlalu tinggi dan labanya akan tertekan. "Di lain pihak, jika aset terlalu rendah, penjualan yang mengutungkan akan hilang" (Houston, Brigham, 2013:136).

Ada beberapa jenis rasio aktivitas yang dapat digunakan sebagai ukuran untuk menilai efiensi sebuah perusahaan dalam mengelola asetnya. Jenis-jenis rasio aktivitas tersebut antara lain perputaran piutang, hari rata-rata penagihan hutang, perputaran persediaan, hari rata-rata penagihan sediaan, perputaran modal kerja, perputaran aktiva tetap, perputaran aktiva.

Rasio perputaran merupakan rasio di mana penjualan dibagi dengan aset. Sesuai dengan namanya, rasio ni menunjukkan berapa kali pos tersebut berputar sepanjang tahun (Brigham dan Houston, 2013:136). Untuk mengetahui efektivitas pengelolaan persediaan dapat dilihat dari perhitungan tingkat perputaran persediaannya, karena semakin tinggi tingkat perputaran persediaan menunjukkan semakin pendek waktu terikatnya modal dalam persediaan sehingga untuk memenuhi volume penjualan tertentu dalam naiknya perputaran persediaan maka dibutuhkan jumlah modal kerja yang kecil.

Pentingnya manajemen persediaan telah dikenal sejak masa lampau. Hal tersebut terbukti dengan tersebutnya pengelolaan persediaan dalam Surat Yusuf ayat 43, 47, dan 48.

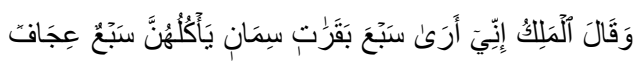

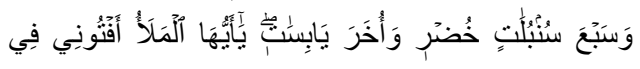

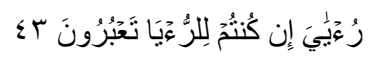

Waqāla al-maliku innī arā sab`a baqarātin simānin ya'kuluhunna sab 'un 'jāfu wasab' sunbulātin khudrin waokhara yābisātin yā ayyuha al-malao aftūni fī ruyāya in kuntum lirruyā ta 'burūn. 
Dewi, et al/Jurnal Ekonomi Syariah Teori dan Terapan Vol. 3 No. 7 Juli 2016: 520-532; DAR DAN PERPUTARAN PERSEDIAAN SERTA PENGARUHNYA TERHADAP PROFITABILITAS PERUSAHAAN TEKSTIL DAN GARMEN YANG TERDAFTAR DI INDEKS SAHAM SYARIAH INDONESIA

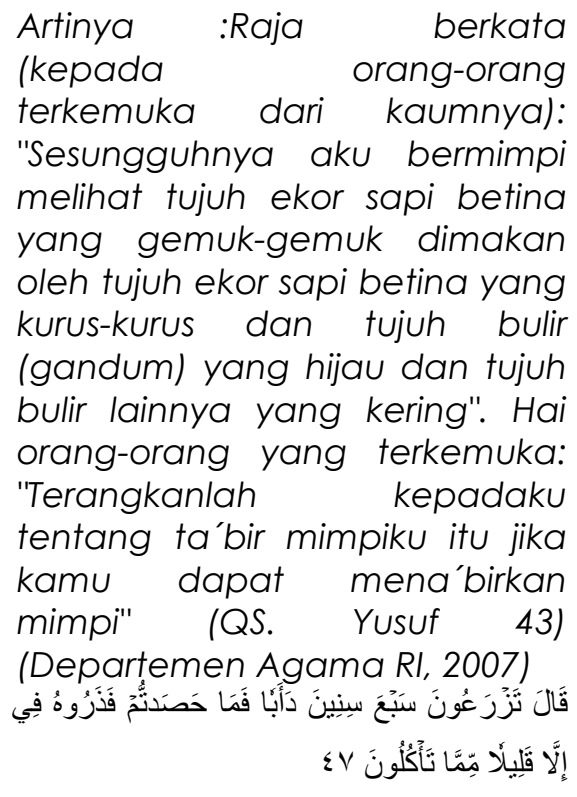

Qāla tazra ‘ùna sab`a sinina da'ban famā hașottum fażarūhu fì sumbūlihī illa qaПian mimmā ta'kulūn.

Artinya: Yusuf berkata: "Supaya kamu bertanam tujuh tahun (lamanya) sebagaimana biasa; maka apa yang kamu tuai hendaklah kamu biarkan dibulirnya kecuali sedikit untuk kamu makan ( QS. Yusuf 47) (Departemen Agama, 2007)

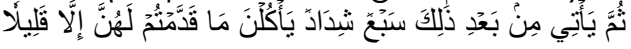

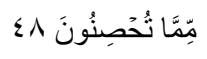

summa ya'tī mimba'di Żālika sab'un syidādun ya'kulna mā qaddamtum lahunna illa qaßian mimmā tuhșinūn.

Artinya :Kemudian sesudah itu akan datang tujuh tahun yang amat sulit, yang menghabiskan apa yang kamu simpan untuk menghadapinya (tahun sulit), kecuali sedikit dari (bibit gandum) yang kamu simpan (QS. Yusuf 48) (Departemen Agama Rl, 2007)

Perputaran persediaan dapat dihitung dengan menggunakan rumus (Houston dan Brigham, 2001:81) :
Inventory Turn Over (ITO) :

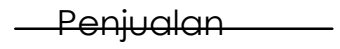

Persediaan

\section{METODE PENELITIAN}

\section{Pendekatan Penelitian}

Pada penelitian ini akan menggunakan pendekatan kuantitatif yaitu penelitian yang menitikberatkan pada pengujian hipotesa dengan alat analisa metode statistik dan menghasilkan kesimpulan yang dapat digeneralisasi. Kuncoro (2011:3) mengatakan bahwa metode kuantitatif adalah pendekatan ilmiah terhadap pengambilan keputusan maanajerial dan ekonomi.

\section{Definisi Operasional Variabel}

1. Debt To Assets Ratio

Rumus :

Debt To Asset Ratio (DAR) :

$$
\frac{\text { Total Debt }}{\text { Total Asset }}
$$

Debt To Asset Ratio merupakan rasio utang yang digunakan untuk menilai utang dengan aset. Rasio ini dicari dengan cara membandingkan antara seluruh hutang dengan seluruh aset. Dengan kata lain rasio ini berfungsi untuk mengetahui setiap rupiah modal sendiri yang dijadikan untuk jaminan hutang (Kasmir, 2013:158).

2. Inventory Turn Over (ITO) 
Dewi, et al/Jurnal Ekonomi Syariah Teori dan Terapan Vol. 3 No. 7 Juli 2016: 520-532; DAR DAN PERPUTARAN PERSEDIAAN SERTA PENGARUHNYA TERHADAP PROFITABILITAS PERUSAHAAN TEKSTIL DAN GARMEN YANG TERDAFTAR DI INDEKS SAHAM SYARIAH INDONESIA

Rumus:

\begin{tabular}{c} 
Inventory Turn Over (ITO) : \\
$\frac{\text { Penjualan }}{\text { Persediaan }}$ \\
\hline
\end{tabular}

rasio di mana penjualan dibagi dengan aset. "Sesuai dengan namanya, rasio ini menunjukkan berapa kali pos tersebut "berputar" sepanjang tahun" (Brigham dan Houston, 2013:(36).

3. Return On Assets (ROA)

Rumus :

Pengembalian atas total asset (ROA) :

$\frac{\text { Laba Bersih }}{\text { Asset }}$

Rasio ini menunjukkan seberapa besar kontribusi aset dalam menciptakan laba bersih. Rasio ini digunakan untuk mengetahui seberapa besar laba bersih yang dihasilkan dari dana yang ditanam dalam aset.

\section{Jenis dan Sumber Data}

Jenis data yang digunakan pada penelitian ini adalah data panel yang merupakan gabungan data runtut waktu (time series) dengan data silang (cross section) beberapa perusahaan yang memenuhi krieris sebagai obyek observasi. Data yang digunakan dalam penelitiaan ini adalah data sekunder. Menurut Siagian dan Sugiarto (2006:17) data sekunder merupakan data primer yang diperoleh oleh pihak lain atau data primer yang telah diolah lebih lanjut dan disajikan oleh pengumpul data primer atau oleh pihak lain. Data didapatkan dengan mengunduh laporan keuangan triwulan yang dipublikasikan di situs resmi Bursa Efek Indonesia.

\section{Teknik Analisis Data}

Tehnik analisis yang digunakan adalah tehnik analisis regresi data panel. Analisis regresi data panel merupakan analisis regersi dengan struktur data panel. Data panel merupakan gabungan dari data cross section dan data time series yang sama diukur pada waktu yang berbeda.

\section{HASIL dan PEMBAHASAN}

Pemilihan model pendekatan pada regresi data panel harus dilakukan terlebih dahulu. Terdapat tiga model pendekatan, yaitu pooled least square (PLS), fixed effect model (FEM), random effect model (REM). Pemilihan model tersebut dapat menggunakan uji chow. Uji chow digunakan untuk melihat model manakah yang paling cocok antara PLS dan FEM.

Hasil yang diperoleh pada uji chow menunjukkan bahwa model yang paling cocok adalah modlel PLS. Setelah diputuskan bahwa model pendekatan yang digunakan adalah PLS maka selanjutnya 
Dewi, et al/Jurnal Ekonomi Syariah Teori dan Terapan Vol. 3 No. 7 Juli 2016: 520-532; DAR DAN PERPUTARAN PERSEDIAAN SERTA PENGARUHNYA TERHADAP PROFITABILITAS PERUSAHAAN TEKSTIL DAN GARMEN YANG TERDAFTAR DI INDEKS SAHAM SYARIAH INDONESIA

dilakukan uji $\dagger$ untuk menegtahui
pengaruh secara parsial dari
variabel DAR dan ITO.
Hasil penghitungan uji $\dagger$ menunjukkan bahwa variabel DAR memiliki nilai probability sebesar 0,7539, maka dari hasil tersebut dapat disimpulkan bahwa nilai probability lebih besar dari tingkat probability yang telah ditentukan yaitu 0.05 atau $5 \%$. Hasil tersebut menunjukkan bahwa nilai DAR berpengaruh tidak signifikan terhadap ROA. Sedangkan untuk variabel ITO memiliki nilai probability sebesar 0,0007, maka dari hasil tersebut dapat disimpulkan bahwa nilai probability lebih kecil dari tingkat probability yang telah ditentukan yaitu 0.05 atau 5\%. Hasil tersebut menunjukkan bahwa nilai ITO berpengaruh signifikan terhadap ROA.

Selanjutnya dilakukan uji $\mathrm{F}$ guna mengetahui pengaruh variabel DAR dan ITO secara simultan terhadap ROA. Hasil dari uji $F$ ini menunjukkan bahwa nilai probability $F$ yang dihasilkan sebesar 0,002685. Nilai $a=$ 0,05 (5\%). Yang berarti bahwa nilai probability $F$ yaitu 0,002685 < nilai a yaitu 0,05. Dapat disimpulkan bahwa dalam pengujian ini variabel DAR dan ITO berpengaruh secara simultan (serempak) terhadap ROA.

\section{Debt To Assets Ratio Terhadap Profitabilitas}

Debt to Assets Ratio
menunjukkan pengaruh tidak signifikan terhadap profitabilitas. Secara umum hal ini dapat terjadi dikarenakan perusahaan enggan memiliki dana eksternal dan cenderung memilih memaksimalkan penggunaan dana internalnya.

$\mathrm{Hal}$ ini selaras dengan teori pecking order yang dikemukakan oleh Myers bahwa perusahaan lebih menyukai menggunakan dana internalnya. Yang dapat diartikan bahwa perusahaan berusaha menjaga level hutang berada level yang rendah.

\section{Perputaran Persediaan Terhadap Profitabilitas}

Perputaran

persediaan menunjukkan pengaruh yang signifikan terhadap profitabilitas. Hal ini dikarenakan perusahaan berhasil mengatur persediaaan dengan efektif. Sehingga persediaan menumpuk ada pada level yang rendah dan tidak memunculkan biaya perawatan yang tinggi sehingga dapat mengurangi profitabilitas.

Hal ini sejalan dengan Houston dan Brigham (2013:136)yang berpendapat "jika perusahaan memiliki terlalu banyak aset yang menggangur, maka biaya modalnya terlalu tinggi dan labanya akan tertekan. "Di lain pihak, jika aset 
Dewi, et al/Jurnal Ekonomi Syariah Teori dan Terapan Vol. 3 No. 7 Juli 2016: 520-532; DAR DAN PERPUTARAN PERSEDIAAN SERTA PENGARUHNYA TERHADAP PROFITABILITAS PERUSAHAAN TEKSTIL DAN GARMEN YANG TERDAFTAR DI INDEKS SAHAM SYARIAH INDONESIA

terlalu rendah, penjualan yang mengutungkan akan hilang"

\section{Debt To Assets Ratio Dan Perputaran Persediaan Terhadap Return On Assets}

Hasil perhitungan statistik juga menunjukkan sejauh mana variabel bebas dapat menjelaskan variabel ROA. Koefisien determinasi berganda adalah nilai statistik yang digunakan untuk mengetahui pengaruh variabel bebas terhadap variabel terikat yang dapat dilihat dari nilai $R 2$ (R-square), yaitu sebesar $10,9599 \%$. Yang artinya variabel ROA dapat dijelaskan oleh variabel bebas sebesar 10,9599\%, sedangkan sisanya $89,0401 \%$ dijelaskan oleh variabel lain yang belum masuk dalam model yang tidak dibahas dalam penelitian ini. Dengan kata lain variabel Debt To Assets Ratio (DAR) serta Inventory Turn Over (ITO) mampu menjelaskan likuiditas saham sebesar 10,9599\%.

Saat sebuah perusahaan memiliki tingkat hutang yang tinggi namun memiliki pengaruh yang negatif pada laba, hal ini dapat diartikan bahwa beban yang ditimbulkan oleh hutang tidak sampai mengurangi atau mempengaruhi laba perusahaan. Pada saat yang bersamaan terjadi efektivitas perusahaan dalam mengelola persediaannya. Hal ini memberi arti bahwa beban biaya yang digunakan untuk merawat persediaan tersebut kecil. Saat beban hutang tidak membebani perusahaan serta persediaan yang dikelola dengan baik sehingga biaya perawatan persediaan kecil, maka perusahaan memiliki kesempatan untuk memiliki laba yang tinggi.

\section{SIMPULAN}

Berdasarkan hasil dan pembahasan pada bab empat, maka kesimpulan yang dapat diambil dari penelitian ini adalah sebagai berikut:

1. Debt To Assets Ratio (DAR) memberikan pengaruh tidak signifikan terhadap ROA perusahaan Tekstil dan Garmen yang terdaftar di Indeks Saham Syariah Indonesia (ISSI) periode 2012-September 2015 yang ditunjukkan dengan nilai probabilitas sebesar 0,7539 yang dimana nilai tersebut lebih besar jika dibandingkan dengan nilai signifikansi yaitu $5 \%$ atau 0,05 .

2. Perputaran Persediaan memberikan pengaruh yang signifikan terhadap ROA perusahaan Tekstil dan Garmen yang terdaftar di Indeks Saham Syariah Indonesia (ISSI) periode 2012-September 2015 yang ditunjukkan dengan nilai probabilitas sebesar 0,0007 yang dimana nilai tersebut lebih kecil jika dibandingkan dengan nilai signifikansi yaitu $5 \%$ atau 0,05 . 
Dewi, et al/Jurnal Ekonomi Syariah Teori dan Terapan Vol. 3 No. 7 Juli 2016: 520-532; DAR DAN PERPUTARAN PERSEDIAAN SERTA PENGARUHNYA TERHADAP PROFITABILITAS PERUSAHAAN TEKSTIL DAN GARMEN YANG TERDAFTAR DI INDEKS SAHAM SYARIAH INDONESIA

3. Variabel Debt To Assets Ratio (DAR) dan Perputaran Persediaan (ITO) terbukti berpengaruh secara signiifikan terhadap variabel dependen ROA perusahaan Tekstil dan Garmen yang terdaftar di Indeks Saham Syariah (ISSI) periode 2012-September 2015

\section{DAFTAR PUSTAKA}

Afrinda, Nindya. 2013. Analisis Pengaruh Likuiditas Dan Solvabilitas Terhadap Profitabilitas Pada Perusahaan Makanan Dan Minuman Yang Terdaftar Di Bursa Efek Indonesia (BEI). Palembang. Fakultas Ekonomi Universitas Sriwijaya

Anshori, Muslich \& Sri Iswati. 2009. Metodologi Penelitian Kuantitatif. Surabaya: Airlangga University Press

Brigham, Eugene F \& Joel F. Houston. 2001. Manajemen Keuangan. Jakarta: Erlangga

Brigham, Eugene F \& Joel F. Houston. 2013. Dasar-Dasar Manajemen Kevangan. Jakarta: Salemba Empat

Draft, Richard L. 2003. Manajemen edisi kelima jilid 2. Jakarta : Erlangga

Departemen Agama RI. 2007. AlQur'anulkarim Terjemahan Per Kata.Bandung: Syaamil Al-Qur'an

Halil, Muhammad. 2013. Pengaruh Rasio Leverage Dan Aktivitas Terhadap Profitabilitas Pada Perusahaan Ritel Yang Terdaftar di Bursa Efek Indonesia (BEI) Periode 2009-2012. Tanjungpinang.
Fakultas Ekonomi Universitas Maritim Raja Ali Haji

Hery. 2015. Analisis Laporan Keuangan Pendekatan Rasio Keuangan. Jakarta: Center For Academic Publishing Service Junita, Ricka. 2006. Analisis Pengaruh Rasio Aktivitas Dan Leverage Keuangan Terhadap Profitabilitas Perusahaan Pada Perusahaan Automotive And Allied Yang Terdaftar Di Bursa Efek Jakarta. Skripsi Fakultas Ekonomi Universitas Riau. Pekanbaru

Kamaliah dkk. 2009. Analisis Pengaruh Rasio aktivitas, Leverage Keuangan, Ukuran, Dan Umur Perusahaan Terhadap Profitabilitas Perusahaan Wholesale and Retail Trade Yang Terdaftar Di Bursa Efek Indonesia. Pekanbaru. Fakultas Ekonomi Universitas Riau

Kasmir. 2013. Analisa Laporan Keuangan. Jakarta: Raja Grafindo Persada

Kuncoro, Mudrajat. 2011. Metode Kuantiatif Teori Dan Aplikasi Untuk Bisnis \& Ekonomi. Yogyakarta : UPP STIM YKPN Kurnia, Meriana. 2014. Pengaruh Debt To Assets Ratio, Current Ratio, Dan Inventory turn Over Ratio Terhadap Return On Assets Pada Perusahaan Manufaktur Yang Terdaftar Di Bursa Efek Indonesia Pada Periode 2009-2012. Tanjungpinang. Fakultas Ekonomi Universitas Maritim Raja Ali Haji

Mulyawan, Setia. 2015. Manajemen Keuangan. Bandung : Pustaka Setia 
Dewi, et al/Jurnal Ekonomi Syariah Teori dan Terapan Vol. 3 No. 7 Juli 2016: 520-532; DAR DAN PERPUTARAN PERSEDIAAN SERTA PENGARUHNYA TERHADAP PROFITABILITAS PERUSAHAAN TEKSTIL DAN GARMEN YANG TERDAFTAR DI INDEKS SAHAM SYARIAH INDONESIA

Myers, Steward C. 2001. "The Capital

Structure Puzzle". The Journal of

Finance. 39/3, 575-592

Rahmawati, Fitri Linda. 2010. Pengaruh

Current Ratio, Inventory turnover, Dan

Debt To Equity Ratio Terhadap Return

On Assets (Studi Pada Perusahaan

Food And Beverage Yang Listing Di

Bursa Efek Indonesia tahun 2007-2009).

Malang. Fakultas Ekonomi Universitas

Negeri Malang

Rasjid, Sulaiman. 2013. Fiqh Islam.

Bandung. Sinar Baru Algesindo

Ross, Westerfield \&Jordan. 2008.

Pengantar Kevangan Perusahaan

(Corporate Finance Fundamental), Edisi

Kedelapan. Jakarta: Salemba Empat

Sari, Ni Made Vironika. 2014. Pengaruh

Debt To Equity Ratio, Firm Size, Inventory

Turnover Dan Assets Turnover Pada

Profitabilitas. Bali. Fakultas Ekonomi Dan

Bisnis Universitas Udayana

Siagian, Dergibson dan Sugiarto. 2006.

Metode Statistika untuk Bisnis dan

Ekonomi. Jakarta: PT Gramedia Pustaka

Utama.

Suhendi, Hendi. 2011. Fiqh Muamalah.

Jakarta : Raja Grafindo Pustaka

Quthb, Syahid Sayyid. 2003. Tafsir Fi Zhilalil-

Qur'an di Bawah Naungan Al-Quran

Jilid 1. Jakarta: Gema Insani Press. 